\title{
Geographies of welcome
}

\author{
The fear of otherness gets ahold of us \\ militant passion \\ what will become of us then? \\ European values \\ that terrorists are said \\ to attack \\ Liberty \\ equality and fraternity? \\ Where can they be found? \\ Income distribution? \\ Where a percentage builds its property \\ borders are open to greed only \\ what if the bombs hit at the deepest? \\ (Jani Nieminen, Bigini, 2016, 110) ${ }^{1}$
}

Forced migration is not a new phenomenon. We can barely imagine a society where some people would not feel accepted as themselves or find their lives threatened. Indeed, as long as there have been societies fleeing their territory has existed as an opportunity to avoid subordination and death when other attempts fail. The causes of forced migration vary over time and space, yet diminished opportunities to provide for oneself and loved ones, differing ideas and opinions about communal life, uneven distribution of resources and division of labour, and disaccord with societal norms and moralities, are enduring reasons for people to flee. While such push factors play a crucial role, migration is rarely driven by them alone, as even when faced with conflict people do not usually leave the place they call home and travel elsewhere without active agency. The characterisation of migration as 'forced' hence already includes a core humanitarian idea: people do not need to put up with everything, there are limits to what is fair and bearable in human life, and these limits can be indicated by leaving behind intolerable circumstances, by means of seeking shelter and better life opportunities elsewhere.

Volume 196 of Fennia takes up a particularly topical approach to forced migration at present, with a focus on the geographies of welcome in the wake of what has been described in popular media and European policy rhetoric as 'the refugee crisis'. Inspired by the Finnish Geography Days 2017 thematised Welcome to Finland? - and Nick Gill's Fennia lecture at the event - titled Welcome: Concept, Culture and Consequences - we are publishing here a critical discussion where geographers are invited to present different perspectives on the idea of welcome, in relation to how it emerged in 2015 and after in Europe, in the context of refuge and asylum seeking. What does welcome mean, in different places and societies? What should it mean, for different quarters and processes? What may it lead to, at different scales and timeframes?

The discussion includes nine commentaries on Gill's (2018) lecture that was expanded and reformulated in our open review process and published as an essay, titled The suppression of welcome (for the Fennia open review process, see Kallio \& Riding 2018). The essay begins by thinking about the tension between official and grassroots responses to the so called 'European refugee crisis', in order to interpret the organisation of 'refugee welcome' in Europe. It aims to initiate a discussion about the nature, practicalities and possible futures of welcome. The text asks the commentators a series of questions which probe what welcoming is, especially when employed in civic discourse by multiple actors as a term associated with the arrival of refugees. Four responses were published and introduced in our first issue of the year (Bagelman 2018; Norum 2018; Vainikka \& Vainikka 2018; Vuolteenaho \& Lyytinen 2018) and the other five are included in this issue.

Matthew Sparke (2018) joins in the conversation by highlighting how geographies of welcome complicate simple binary oppositions between fully enfranchised citizenship and what is often theorized after Agamben as the 'bare life' of refugee rejection in 'spaces of exception' - ranging from sanctuary cities and squats to clinics, classrooms, kitchens and gardens. Spaces of welcome instead offer islands of limited enfranchisement, agency and hope amidst seas of sub-citizenship, subjugation 
and fear. In response to Gill's (2018) call, Sparke reminds us that in-between spaces may be linked up with the liberal humanitarian management of welcome to offer sanctuary amidst sub-citizenship. He illustrates ongoing opportunities for such agency in the face of suppression, and suggests that we need to abandon or at least supplement abstract critiques of liberal humanitarianism, which assume exceptionalism and rejectionism are always and everywhere inevitable.

Jonathan Darling (2018) continues the debate drawing upon a decade of fieldwork in a drop-in centre for asylum seekers and refugees in the city of Sheffield, UK. He takes Gill's (2018) essay as a starting point for reflection on how 'cultures of welcome' are produced. In considering the implications of the 'suppression of welcome', Darling argues for a focus on welcoming as a negotiated process that involves varying durations, demands and levels of commitment. It is this question of an appropriate response, ethical responsibility, to which he returns to in conclusion. Drawing upon Derrida, Darling concedes welcoming cannot be fully organised and known in advance, rather it represents a disposition towards others that is drawn upon in a moment, an ethics that is embodied and felt. It is this thread of responsiveness, of expressing welcome as a form of social justice that runs through the varied modes of welcoming. While not always successful, the labour of keeping such signs visible and friendships alive maintains a 'culture of welcoming'.

John Morrissey (2018) reflects on attendant questions of security and responsibility in seeking to conceptualise a more human-centred vision of populations and population management in our current moment of refugee crisis in Europe. He charts how we might productively conceptualize and enact a 'human security' vision, how such a vision requires us to think differently and cooperatively about security, and ultimately how this compels us to supplant a prevailing narrative of external threat and risk with a story of shared precarity, human empathy and collective responsibility. This reflection on Gill's (2018) essay is concerned with the reluctance to call for the state and its various administrative structures and legal armatures to support and enact welcome. Morrissey argues that there may be more to be said in terms of state responsibilities, and the responsibilities of transnational, collectivestate organisations such as the European Union, towards human security and the protection of human rights for refugees and asylum seekers. To this end, he reflects on a 'human security' vision of population management in a transnational context, which behoves us to think anew 'security', and, crucially, to vigorously contest how its parameters are discursively defined and framed.

Jussi Laine (2018) continues this line of thought, emphasising the complexity and multifacetedness of welcome. He highlights the significance of the processes of identitary bordering and the psychological need for ontological security in seeking to address Gill's (2018) inquiry into what extent should states be engaged in efforts to organise welcome, given their place in the international state system that underpins exclusionary and subjugating border control in the first place. He underlines efforts to debunk tenacious false narratives about migration and to provoke debate in a fashion that will lead to a nuanced understanding of the root causes and motivating factors behind the migrant flows. Laine seeks to break away from the dominant migration-security nexus by pointing towards the opportunities welcoming migrants can bring and elucidating them as valuable resources, rather than a burden, or 'ills' affecting the body of 'national' societies. He argues that simply depicting the governmental perspective in opposition to that of the people is reductive, and that it is this mounting polarization rather than refugees and asylum seekers, which are putting Europe's democracies, social model, and cooperation as values to the test.

To conclude this discussion over two issues of Fennia, Elisa Pascucci (2018) moves the debate elsewhere, and draws on recent research with aid workers in Jordan and Lebanon - as well as on examples from Greece and Italy - proposing the notion of refugee welcome as care work as a possible way to achieve grounded critical understanding. Framing the issue in such a way enables her to ask not only, as Gill (2018) poignantly does, what is welcome, but also where is welcome actually located and, most importantly, who welcomes. Pascucci illustrates the need for a more nuanced understanding of the relation between bureaucratic control and the affective, embodied, spontaneous and caring character of "alternative" forms of welcome. Importantly, the response offers a number of insights that challenge Eurocentric humanitarian conceptions of welcoming refugees, like the centrality of emotional labour and the emerging South-South geographies of hospitality and aid. In so doing, she illuminates the many overlooked forms of labour without which state-centred, institutional, and 
internationally-organized aid and welcome would not be possible - labour which is often feminized, racialized, and precarious. Considering refugee assistance as care work, and the aid and charity sectors as employers, allows Pascucci to expose the gendered and racialized labour relations that obscure such practical and embodied knowledges. She asks an important question in the final piece of our ongoing debate regarding refuge, welcoming, and asylum seeking in the contemporary world: How can geography assist us in such endeavor, and why is it relevant?

We are prepared to continue publishing the discussion in our next volume should scholars, activists, and care workers wish to state additional perspectives, in order to expand this debate, taking it in new directions, or introducing insights from other geographical contexts. So, as you read, please note any emerging thoughts and let us know about them in the form of a comment, a Reflections piece, or a longer paper (for a description of the aims of Reflections, see Kallio 2017). In this vein, we include a final vignette here for you to ponder whilst reading, a comment by Joshua Mullenite, who responded to our question posed to critical geographers regarding concerns on refuge and asylum seeking in the contemporary populist world (posted on CRIT-GEOG-FORUM on November 20 2018).

My concerns with refuge and asylum seeking center largely around the compression of the world's most marginalized communities with the rapidly increasing onset of global climate change. O'Brien and Leichenko's (2000) coining of the term 'Double Exposure' to describe the ways in which individuals and communities most likely to experience the negative effects of climate change and economic globalization continues to be apt here even if the political processes and motivations have changed. As they and others have continued to point out, it is the impoverished populations who will experience the first and worst impacts of the coming climatological storm. This is not only because they largely continue to live on the most marginal lands, but also because they lack the resources to adapt or escape. The growth of populist governments has and likely will continue to lead to the hardening of international borders and an increased difficulty for these populations to seek refuge. This squeeze could cost millions of lives over the next several decades.

The proposed responses to these dual challenges seem almost utopian in nature and - I fear continue to place the burden of risk (of leaving, of traveling, and of arriving) on these marginalized people. Being a smiling face after that grueling and life threatening journey is not enough. That academics who often voice so many critical and radical opinions on such matters continue to espouse - in the lunchrooms and lecture halls of our campuses as well as in the pages of our journals - a sympathetic but also largely policy- or state-oriented approach to addressing (un) welcoming behaviors is troubling to me, even if it is unsurprising. What kind of timelines do state responses require? How do those of us in the imperial world ensure that our recommendations are not simply providing new spaces for imperialism to enter into marginalized people's daily lives? What gets lost in the inevitable negotiating responses?

In this case, Nick Gill's highlighting of the autonomous forms of welcome is a much needed contribution. But as academics, who even among our more precarious are afforded a number of privileges, we should be ready to go much further. This is especially true for those fortunate enough to have positions in countries that are more likely to be receivers of asylum seekers rather than producers of them. Rather than just being voices of moral reason, policy advocates, or highlighters of dissent, l'd like to see academics become (better) accomplices with the world's marginalized. What direct actions can we take to improve the material conditions of actual and would-be refugees here and now? How can we make their journey's safer and in general reduce the risks they face on a timeline that will not result in further deaths? When they arrive in our countries and at our borders, what kinds of spaces, opportunities, and material support can we provide?

As part of their courses my first year students work with refugees in a variety of capacities throughout the semester. They learn about their lives and their humanity. Part of this involves spending times in the ghettoes in which refugee populations are placed, much to the consternation of some of my colleagues who feel it is unsafe to send students into these neighborhoods alone. The student response has been markedly different. They are aware that the neighborhood experiences higher levels of crime than the surrounding areas, but rather than asking why there isn't a greater police presence, or more state-funding for these communities, or even why these ghettoes are the homes of refugees, they asked why ghettoes exist at all. The very idea that such spaces can be socially constructed to isolate and demarcate communities was absurd to a group of 17-19 year olds and it should be equally absurd to us. What can we do to dismantle them and the socioeconomic conditions that uphold them? Smiling faces and more welcoming behaviors cannot be the totality of that answer, even if they are important components.

The recent IPCC reports noting the incredibly short timelines for irreversible global catastrophe 
make it clearer than ever that we can no longer sit on our hands. At the same time, it is the global (potential) refugee and asylee populations that are already experiencing the worst of these impacts. Thus my ultimate concern is, on the timelines we have, how do we ensure that we aren't simply creating global refugee ghettoes as people face the coming squeeze?

This issue of Fennia includes four original research papers, one shorter paper in the Reviews and Essays section, and five Reflections texts. We begin with two articles discussing local governance in two Finnish borderland contexts. The first article, by Fredriika Jakola (2018), Local responses to state-led municipal reform in the Finnish-Swedish border region: conflicting development discourses, culture and institutions, analyses development discourses in the Kemi-Tornio region, at the North West borderland of Finland. Focusing on the views of municipal actors, the paper looks into the mobilization and strategic usage of the local institutional environment, and the border location in particular, as they appear in policy documents and interviews with key municipal actors in the region. The analysis reveals, among other things, distinct relations to state-led and EU discourses, and unbalanced power relations between municipalities. Based on her findings, Jakola suggests that state-led municipal reforms would be better accomplished if municipalities were considered equal partners, instead of implementers of the state's will.

The second article, The commons and emergent land in Kvarken Archipelago, Finland: governing an expanding recreational resource by Kristina Svels and Ulrika Åkerlund (2018), presents results from a study focusing on the governance structures at the Kvarken Archipelago landscape in South West Finland. In question is a geographically particular area - and a designated UNESCO World Heritage site - where continuous and relatively fast land rise creates shore displacement and produces new land. The place is increasingly populated by second-home owners and users, which in the Finnish context does mean elites but mostly middle-class people who organize their lives between urban housing and rural 'cottaging' (see also Kietäväinen et al. 2016). Svels and Åkerlund's study targeted specifically the overlapping use rights between private and collective actors, related to the recreational resource system, from local actors' perspectives including professionals, authorities, and lay people as individuals and collectives. The results indicate that, in contexts where natural resource systems are complex, values mixed, and different quarters draw from the same resource units, a multidimensional approach is required for understanding the decision making procedures tensed by various power relations.

The third article of this issue, Perfect food: perspectives on consumer perceptions of fresh produce quality, shifts the focus to the US context, specifically Fredericksburg in Virginia, and to the topic of sustainable food production and consumption. In her paper Caitlin Finlayson (2018) discusses consumer approaches to fresh produce quality, and how the (changing) consumer behaviour may impact on the practices of retailers and food waste at the supply chain. Drawing from interviews with local food vendors - some with rather traditional concepts and others emphasising alternative forms of food production - she has found consumers in this empirical context to have mostly anticipated expectations of how fresh products should look like, what Finlayson calls 'perfection'. However, it seems that people's awareness may grow, and attitudes and practices change, if they come to build relationships with food producers. Based on the discussions with farmers, produce stand vendors, and supervisors, Finlayson suggests in conclusion that learning more about growing processes and difference between organic and conventional farming methods may initiate change in terms of sustainable food production.

Our fourth original research article by Juha Ridanpää (2018) focuses on minority languages from the perspective of language revitalisation. The paper is titled Why save a minority language? Meänkieli and rationales of language revitalization, and its empirical context is East North Sweden, Torne Valley, where Meänkieli exists as a diminishing minority language. Discussing the current situation and the future prospects of the language with cultural activist who contribute to its revitalisation, Ridanpää has located a contradictory landscape. While varying motivations for saving the language as well as how to operationalise the process exist, it seems evident that such processes ought to take seriously the distinct identities that people carry, which may involve multiple layers of attachment and estrangement. In the case of Meänkieli, reflection with the long history of marginalisation and 
people's personal relations within this history cannot be ignored in efforts to maintain the language as a living practice.

In addition to original articles, included in this issue is a short paper by William Conroy (2018) that provides an overview of the critical study of brownfields, taking up three theoretical perspectives. The paper titled Studying brownfields: governmentality, the post-political, or non-essential materialism? draws from his own study of the brownfield (re)development in the Fairfield County and the city of Bridgeport, Connecticut, US. The article assess the analytical opportunities offered by three theoretical approaches to this specific case study, which he terms 'governmentality', 'post-political' and 'nonessentialist materialism'. Finding each of the approaches deficient with regard to their conceptions of the subject and political agency, Conroy proposes in conclusion a 'world-ecology approach' as a more nuanced theoretical ground for studying what he sees as the neoliberal brownfield redevelopment.

With these five articles and five discussion pieces, we wish you all a good end of the semester, and hope that the issue will lead to further debates in geography and beyond.

KIRSI PAULIINA KALLIO

FENNIA EDITOR-IN-CHIEF

JAMES RIDING

FENNIA REFLECTIONS SECTION EDITOR

\section{NOTES}

${ }^{1}$ Translation by K. P. Kallio.

\section{REFERENCES}

Bagelman, J. (2018) Who hosts a politics of welcome? - commentary to Gill. Fennia 196(1) 108-110. https://doi.org/10.11143/fennia.70294

Conroy, W. (2018) Studying brownfields: governmentality, the post-political, or non-essential materialism? Fennia 196(2) 204-214. https://doi.org/10.11143/fennia.70295

Darling, J. (2018) The fragility of welcome - commentary to Gill. Fennia 196(2) 220-224. https://doi. org/10.11143/fennia.75756

Finlayson, C. (2018) Perfect food: perspectives on consumer perceptions of fresh produce quality. Fennia 196(2) 168-186. https://dx.doi.org/10.11143/fennia.65645

Gill, N. (2018) The suppression of welcome. Fennia 196(1)88-98. https://dx.doi.org/10.11143/fennia.70040

Jakola, F. (2018) Local responses to state-led municipal reform in the Finnish-Swedish border region: conflicting development discourses, culture and institutions. Fennia 196(2) 137-153. https://doi. org/10.11143/fennia.69890

Kallio, K. (2017) Subtle radical moves in scientific publishing. Fennia 195(1) 1-4. https://doi.org/10.11143/ fennia.63678

Kallio, K., \& Riding, J. (2018) Dialogical peer-review and non-profit open-access journal publishing: welcome to Fennia. Fennia 196(1) 4-8. https://doi.org/10.11143/fennia.70470

Kietäväinen, A., Rinne, J., Paloniemi, R., \& Tuulentie, S. (2016) Participation of second home owners and permanent residents in local decision making: the case of a rural village in Finland. Fennia 194(2) 152-167. https://doi.org/10.11143/55485

Laine, J. (2018) Conditional welcome and the ambivalent self - commentary to Gill. Fennia 196(2) 230235. https://doi.org/10.11143/fennia.76101

Morrissey, J. (2018) Envisioning human security - commentary to Gill. Fennia 196(2) 225-229. https://doi. org/10.11143/fennia.76029

Nieminen, J. (2016) Bigini. Like, Helsinki.

Norum, R. (2018) From welcome to well ... come: the mobilities, temporalities and geopolitics of contemporary hospitality - commentary to Gill. Fennia 196(1) 111-117. https://dx.doi.org/10.11143/ fennia.70403 
O'Brien, K.L. \& Leichenko, R. (2000) Double exposure: assessing the impacts of climate change within the context of economic globalization. Global Environmental Change 10(3) 221-232. https://doi. org/10.1016/S0959-3780(00)00021-2

Pascucci, E. (2018) Who welcomes? The geographies of refugee aid as care work - commentary to Gill. Fennia 196(2) 236-238. https://doi.org/10.11143/fennia.76588

Ridanpää, J. (2018) Why save a minority language? Meänkieli and rationales of language revitalization. Fennia 196(2) 187-203. https://dx.doi.org/10.11143/fennia.74047

Sparke, M. (2018) Welcome, its suppression, and the in-between spaces of refugee sub-citizenship commentary to Gill. Fennia 196(2) 215-219. https://doi.org/10.11143/fennia.70999

Svels, K. \& Åkerlund, U. (2018) The commons and emergent land in Kvarken Archipelago, Finland: governing an expanding recreational resource. Fennia 196(1) 154-167. https://dx.doi.org/10.11143/ fennia.69022

Vainikka, V. \& Vainikka, J. (2018) Welcoming the masses, entitling the stranger - commentary to Gill. Fennia 196(1) 124-130. https://doi.org/10.11143/fennia.70227

Vuolteenaho, J. \& Lyytinen, E. (2018) Reflections on the variations and spatialities of (un)welcome commentary to Gill. Fennia 196(1) 118-123. https://doi.org/10.11143/fennia.70290 